\title{
Energy efficiency of housing as a tool for sustainable development
}

\author{
Vasiliy Stoikov ${ }^{1, *}$ and Violetta Gassiy ${ }^{2}$ \\ ${ }^{1}$ Moscow State University of Civil Engineering, Yaroslavskoe shosse, 26, Moscow, 129337, Russia \\ ${ }^{2}$ Kuban State University, 350040, Krasnodar, Stavropolskaya st., 149.
}

\begin{abstract}
The paper aims to determine the role of energy efficiency of buildings to achieve sustainable development goals. The study objects are the mechanisms, tools and principles of state regulation of energy efficiency, construction of buildings and houses, the green economy development. The materials and methods of the study are data information on energy efficiency principles in the EU and Russia, government programs in the implementation of mechanisms and approaches for the green economy development, as well as methods of comparative and system analysis. The authors conclude on the need for further development of the principles of energy efficiency and resource conservation, the importance of sustainable development in order to ensure a high standard of living of the population.
\end{abstract}

\section{Introduction}

Recently, there are many requirements for construction, one of which is the rational use of energy. This is a prerequisite to the fact that when designing any object, it is necessary to develop the section "Energy Efficiency", which is aimed at optimal energy consumption in buildings or structures in order to create the most comfortable conditions for the life of the people living there.

Over the past decades, the uncontrolled mining and wasteful use of non-renewable energy resources mankind has approached the global crisis of world fuel reserves, as well as a significant deterioration of the ecological situation on the planet: climate warming, disease, air pollution, rivers, deforestation.

Experts predict that, moving at such a pace, we will completely consume the reserves of natural energy resources (gas, oil, coal) in the next fifty years. A serious energy crisis in the 1970 s of the 20th century made Europe think about environmental issues and start developing environmental projects. In 2015, the Paris Agreement on Climate was signed, regulating measures to reduce carbon dioxide in the atmosphere since 2020.

This agreement is based on three basic principles - the most important provisions, from which all subsequent actions follow. First, all countries agreed to take measures to limit greenhouse gas emissions so that the average temperature throughout the world does not rise by more than two degrees by the end of the century (with the prospect of limiting it to

\footnotetext{
* Corresponding author: stoikov.vf@mail.ru
} 
1.5 degrees). Secondly, these measures and restrictions should be reviewed regularly every five years. And thirdly, a fund will be formed to help developing countries to combat changes and the effects of climate change in the amount of at least $\$ 100$ billion annually [1].

\section{Theoretical background}

The scientific work of scientists and researchers are devoted to the problems of energy efficiency of buildings and its significance for construction. In recent years, the idea of sustainable development and the principles of a green economy, their importance for ensuring the quality of life of the population have been actively developing. Professor Potravny I. considers green building as an important stage in implementing the principles of sustainable development, the need to develop green entrepreneurship as the basis for innovation in the regional economy. Zeiler W. and Boxem G. in their studies, they examine in detail the quality of buildings through the classification of houses, which involves dividing them into categories: active and passive houses. This makes it possible to compare their energy performance, resource conservation and energy efficiency. Volkov A.A., Vakhidova B.R. study the practice of introducing energy efficiency mechanisms in the EU and offer integral models that can be used in the Russian context. In particular, in their works the mechanisms of stimulating the activity of entrepreneurs in the field of construction for the introduction of resource-saving technologies were considered. Ron Judkoff considers green building as a result of the development of innovations, innovations in the development of new materials characterized by energy efficiency and resource saving. Stoikov V. and Gassiy V. also link the principles of energy efficiency with innovative approaches, the creation of new types of materials, as well as the development of state methods to encourage entrepreneurs to introduce innovations in the construction industry. The scientists consider the mechanism of public-private partnership plays important role in the green construction development, which is able to accumulate administrative and financial resources to accelerate the introduction of innovations and implementation of sustainable development principles.

\section{Materials and methods}

In most countries of the world, requirements to increase thermal protection of buildings have become one of the most important objects of state regulation. In addition to saving public energy, these requirements are designed to protect the environment from harmful emissions, rational use of natural resources, reducing the "greenhouse effect".

Table 1. Estimated Annual Rate of World building energy consumption [2]

\begin{tabular}{|c|c|}
\hline Year & Energy consumption (quads/year) \\
\hline 2004 & 72,2 \\
\hline 2010 & 82,2 \\
\hline 2015 & 90,7 \\
\hline 2020 & 97,3 \\
\hline 2025 & 103,3 \\
\hline 2030 & 109,7 \\
\hline
\end{tabular}

Today, the problem of reducing the energy consumption of residential buildings is urgent, which also gave impetus to the development of energy-saving technologies. Up to $40 \%$ of all energy resources of the country are spent on heating homes by states, and as a result huge amounts of carbon dioxide are emitted into the atmosphere, which leads to the 
development of the "greenhouse effect". Energy-saving technologies allow solving several problems at once:

1. Energy Saving

2. The solution to different problems of housing

3. Reducing pollution.

4. Increasing the profitability of enterprises.

According to the Buildings Performance Institute Europe (BPIE), renovation of residential buildings on the basis of energy efficiency in the long run leads to an improvement in social indicators of society, such as health, availability of heat for low-income families, and comfort [3]. It is necessary to mark that EU is the third energy consumer after China's $(23 \%)$ and US' $(17 \%)$ shares of global energy consumption. Among the structure of the energy sources we can divide the EU energy market by following sources [4]:

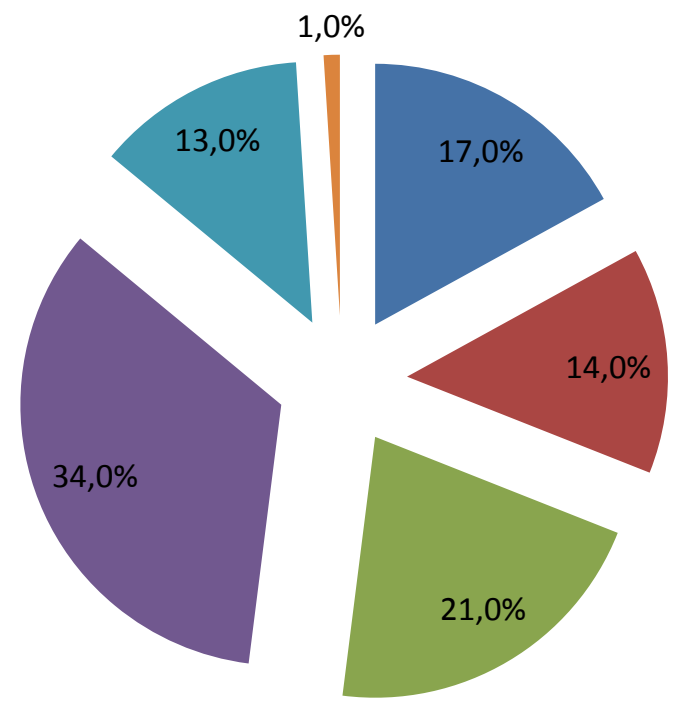

Solid fuels

Nuclear

Oil

RES

Gaz

Other

Fig. 1.Energy consumption by source in EU in 2016

At present, Russia has room to develop in the matter of using energy-saving technologies. According to experts, Russia has a huge potential, more than $40 \%$ of the total level of energy consumption, energy efficiency [5]. Russian houses have very low energy efficiency, huge energy losses. According to the State Construction Committee, in Russia the consumption of heat (heating, hot water) is $74 \mathrm{~kg}$ of standard fuel per square meter. per year, which is several times higher than in Europe. The energy consumption of many Russian enterprises is about twice as high as in developed countries. And although in European countries, energy-saving technologies are becoming increasingly popular, in Russia they still do not pay enough attention. One of the main reasons for their slow spread is considered to be the lack of interest of homeowners, they are not adequately explained all the ways and means to modernize the home. The most that an ordinary citizen will do is to replace electricity meters with new ones, with differential charging. There is not enough work by the state apparatus in stimulating the construction of energy-efficient buildings. For example, the benefits in taxation for companies engaged in the construction of such housing.

After the adoption in Russia of Building Regulations and Rules 23-02-2003 "Thermal Protection of Buildings", it is possible to increase the energy efficiency of houses under construction, but with insufficient economic incentives, many companies continue to invest in the construction of buildings with low energy savings, this allows them to save by reduc- 
ing energy efficient construction costs. These building codes set requirements for the level of thermal protection of buildings in order to save energy. At the same time, the sanitary and hygienic norms of the microclimate of the premises and the optimal durability parameters of the enclosing structures of buildings and structures should be observed.

In 2009, the State Duma adopted the federal law "On Energy Saving and Increasing Energy Efficiency", according to which all buildings put into operation, as well as during operation, must comply with energy efficiency requirements and have energy metering devices. The law defines a set of measures to realize the possibility of saving due to energyefficient goods and services [6]. A ban on the production and sale of incandescent bulbs of 100 watts and more, from 2013 - 75 watt lamps, from 2014 - 25 watt lamps. Energy assessments should be carried out by special organizations in order to draw up measures for energy saving and energy efficiency. The law provides for long-term methods of tariff regulation, in which utility companies have an incentive to reduce energy costs and improve energy efficiency in their use. The resulting savings remain with the company and can be spent on any purpose.

For enterprises and individual entrepreneurs, introducing energy-saving technologies, a mechanism of budget subsidies, the provision of tax benefits and reimbursement of interest on loans for technology projects [7].

Also, the Russian government approved the program "Energy saving and energy efficiency for the period until 2020" [8]. The program provides for gas savings of 330 billion cubic meters, electricity - 630 billion kWh, heat energy - 1550 million Gcal, oil products 17 million tons. As can be seen, the government is taking steps to introduce energy-saving technologies.

\section{Research results}

Until the beginning of the 90 s, research on energy saving measures was the main interest in the construction of energy-efficient buildings. The construction of "Sustainable building" has become the logical conclusion of the development stages of energy-efficient buildings. These buildings combine: a comfortable indoor climate, maximum use of natural energy, optimized energy elements of buildings as a whole [9].

There are methodologies for certification of buildings in terms of energy efficiency [10]. In 2002, a new law on energy efficiency in buildings of EU member states was adopted. The Directive 2002/91 / EC entered into force in 2003, it establishes general principles for the energy performance of buildings. In accordance with this law, the energy efficiency of buildings is the actual consumption or estimated amount of energy for various purposes associated with ordinary use, in particular heating, water heating, cooling, ventilation and lighting. The amount of energy, in this case represented by one or more numeric values. They take into account the insulation, technical characteristics of the installation, orientation relative to the incoming solar radiation, the impact of the surrounding buildings, their own energy production. Of course, it also takes into account a factor such as the indoor climate in the room, which affects the need for energy.

Housing in EU countries are divided into an ordinary house (energy consumption 400 kWh per 1 sq. M per year), "passive house" (consumption no more than $15 \mathrm{kWh}$ ), and "active house" [11].

"Passive house" emits little heat due to thermal insulation, which provides the effect of "thermos", thereby providing a comfortable temperature in the house throughout the year. "Thermos Effect" is a closed heating system and recuperative ventilation. These homes consume $80 \%$ less energy. Today, the "passive house" is the leading standard for energy efficiency in the world. In 2000-2001, pilot sites of "passive" low- and high-rise buildings and residential villages were built in five countries of Western Europe. The program was 
funded in the late 90 s by the EU under the name "Gefeos". In Germany, these houses more than six thousand. These houses also began to be built in Sweden, Austria, Finland and Switzerland. In North America in the city of Urbana (Illinois, USA), the first "passive house" was built in 2003. Such houses cost 10-25\% more expensive than an ordinary house, but they spend $90 \%$ less energy to heat and the house pays off within seven to ten years.

"Active home" is the next step in the development of "passive home". This house can produce all the electricity and hot water. Hot water in these houses is obtained through the use of solar panels, and a solar power station and heat pump are installed on the roof of the "active" house, which converts the low potential heat of the earth or domestic wastewater into hot water.

\section{Conclusions}

Thus, at present, research institutes and industrial manufacturers offer a wide range of technological solutions that provide residential buildings with increased energy efficiency: weatherization of facades, lightweight concrete, window designs, ventilation systems with heat recovery, widely enclosed building structures, metering and thermal control systems etc. All these solutions are well known to specialists and, if there are sufficient incentives, they can be quickly implemented in construction. The main factor limiting the use of efficient energy technology solutions in the construction industry today is the lack of coordinated and targeted public policy. The most important task is to form the basis for building energy efficiency standards.

The paper is prepared by the financial support of RFBR, projects N 17-02-00249-OГH.

\section{References}

1. Judkoff R. Increasing Building Energy: efficiency Through Advances in Materials // Harnessing Materials for Energy: MRS bulletin. - Vol. 33. - April, 2008. URL: www.mrs.org/bulletin

2. A guide to developing strategies for building energy renovation. Buildings Performance Institute Europe (BPIE), 2013.

3. Stoykov V.F., Gassiy V.V. Green technologies in construction as a stimulus for the development of a regional economy // The horizons of the economy. 2017. No. 5 (38). pp. 78-84.

4. Energy Efficiency in Europe. The levers to deliver the potential. Deloitte Conseil, 2016.

5. Volkov A.A., Vakhidova B.R. Energy saving in construction: from EU countries experience // Interactive Science, N 7, $2016 . \quad$ - pp. 33-36. URL: https://cyberleninka.ru/article/n/energosberezhenie-v-stroitelstve-iz-opyta-stran-es

6. Federal law of 23.11.2009, № 261-FZ "On energy saving and on increasing energy efficiency and on introducing amendments to certain legislative acts of the Russian Federation". URL: http://kremlin.ru/acts/bank/30163

7. State program "Energy Efficiency and Energy Development" approved by the Government Decree of April 15, 2014 No. 321. URL: http://government.ru/programs/227/events/

8. Potravny I.M., Lukyanova Yu.S. Support directions of "green" construction development in Russia // Proceedings of the VIII International Scientific and Practical Conference of the Department of Project and Program Management "Modern problems of 
project management in investment and construction and nature management", 11-15 April, 2018. - pp. 243-247.

9. Gassiy V., Potravny I. The assessment of the socio-economic damage of the indigenous peoples due to industrial development of Russian Arctic // Czech Polar Reports. 2017. Vol. 7. N2. pp. 257-270

10. ILETE Labelling and certification guide. URL: https://ec.europa.eu/energy/intelligent/projects/sites/ieeprojects/files/projects/documents/ilete_labelling_and_certification_guide_en.pdf.

11. Zeiler W., Boxem G. (2009). Active house concept versus passive House. In R. Vehler, M. Verhoeven, \& M. Fremouw (Eds.), Proceedings of the 3rd CIB International conference on Smart and Sustainable Built Environments (SASBE2009), June 15-19 2009, Delft (pp. 1-8). Delft: Delft University of Technology 